\title{
KUALITAS PELAYANAN DALAM PENGURUSAN PASPOR DI KANTOR IMIGRASI KELAS I MAKASSAR
}

\author{
${ }^{1}$ Ulfi Tantri Wahid, ${ }^{2}$ Ruskin Azikin, ${ }^{3}$ Adnan Ma'ruf \\ 1) Jurusan Ilmu Administrasi Negara Fisipol Unismuh \\ 2) Jurusan Ilmu Administrasi Negara Fisipol Unismuh \\ 3) Jurusan Ilmu Administrasi Negara Fisipol Unismuh
}

\begin{abstract}
The objectives of this research are to find out the service quality and to investigate the supporting and the inhibiting factors of passport handling at the first class Immigration Office of Makassar. There are 13 informants involved in this research. The type of this research is qualitative research with phenomenological type which is emphasized to the subjectivity of human life experiences. The data were collected by using observation and interview. The results of this research reveal that the service is still less qualified. It can be identified from some aspects such as Empathy in which some officers still act unfairly in the service process. Other aspects such as Tangible, Reliability, Responsiveness, and Assurance have been conducted optimally. The supporting factors are the adequate facilities and infrastructures while the lack of public awareness becomes the inhibiting factor of the service.
\end{abstract}

Key word: Service quality, passport handling.

\begin{abstract}
ABSTRAK
Tujuan penelitian adalah untuk mengetahui kualitas pelayanan dan mengetahui faktor pendukung dan penghambat dalam pengurusan paspor di Kantor Imigrasi Kelas I Makassar. Jumlah informan dalam penelitian ini adalah 13 orang. Jenis penelitian ini menggunakan kualitatif dengan tipe penelitian menggunakan tipe fenomenologi yaitu menekankan pada subyektivitas pengalaman hidup manusia. Teknik pengumpulan data menggunakan metode observasi dan wawancara. Hasil penelitian menunjukkan bahwa belum tercapai secara maksimal hal ini dilihat dari aspek Empathy (perhatian) dimana masih ada oknum petugas yang bertindak secara tidak adil dalam proses pelayanan, dilihat dari aspek lain seperti Tangible (bukti langsung), Reliability (kehandalan), Responsiveness (daya tanggap) dan Assurance (jaminan) sudah tercapai secara maksimal. Faktor pendukung adalah fasilitas sarana prasarana dan faktor penghambat adalah kurangnya kesadaran masyarakat.
\end{abstract}

Kata Kunci : Kualitas Pelayanan, Pengurusan Paspor 


\section{PENDAHULUAN}

Berdasarkan

peraturan

pemerintah Nomor 25 Tahun 2009

Pelayanan merupakan segala kegiatan dalam rangka pemenuhan kebutuhan dasar sesuai dengan hakhak dasar setiap warga negara dan penduduk atau suatu barang, jasa, dan atau pelayanan administrasi yang disediakan oleh penyelenggara pelayanan yang terkait dengan kepentingan publik. Di negaranegara berkembang dapat kita lihat mutu pelayanan publik merupakan masalah yang sering muncul, karena pada negara berkembang umumnya permintaan akan pelayanan jauh melebihi kemampuan pemerintah untuk memenuhinya sehingga persoalan yang sering dikritisi masyarakat atau para penerima layanan adalah persepsi terhadap "kualitas" yang melekat pada seluruh aspek pelayanan. Karena itu pemerintah harus memberikan pelayanan terbaik kepada masyarakat.

Menurut Wasistiono dalam Sagita (2010) pelayanan adalah pemberian jasa baik oleh pemerintah, pihak swasta atas nama pemerintah ataupun pihak swasta kepada masyarakat, dengan atau tanpa pembayaran guna memenuhi kebutuhan dan kepentingan masyarakat. Tugas pelayanan masyarakat (public service) lebih menekankan kepada mendahulukan kepentingan publik, mempermudah urusan publik, mempersingkat waktu proses pelaksanaan urusan publik, dan memberikan kepuasan kepada publik.

Berbicara mengenai pelayanan paspor di Kantor Imigrasi Kelas I Makassar ternyata juga tidak jauh dari sorotan public (masyarakat). Baik dari sisi pengawasan dan pertanggung jawaban kinerja pegawai/petugas yang tidak maksimal yang kemudian melahirkan stigma dari masyrakat bahwa adanya pengawasan yang kurang baik.

Belakangan ini telah di ketahui bahwa kondisi tersebut di sebabkan tidak ada ketegasan dari pegawai/petugas, terkadang karena faktor keluarga yang datang untuk mengurus paspor sehingga datanya 
sering di dahulukan dalam pengurusan tidak sesuai dengan proses yang telah di atur dan bahkan pula ada yang tidak ikut mengantri dalam pengurusan paspor karena faktor keluarga/kerabat dan disinilah faktor lemah petugas dalam pengawasan. Kemudian masalah yang lain yaitu seringnya terjadi keterlambatan dalam pengurusan paspor hal ini di akibatkan karena adanya kerusakan pada sistem jaringan di Kantor Imigrasi Kelas I Makassar. Berdasarkan hal tersebut banyak masyarakat yang mengeluh tentang pelayanan yang ada di Kantor Imigrasi Kelas I Makassar.

Harapannya adalah untuk meningkatkan kepuasan pada masyarakat dan mempermudah dalam hal mendapatkan pelayanan ketika mengajukan permohonan penerbitan paspor di kantor Imigrasi akan tetapi kenyataannya tidak sesuai dengan harapan yang ada karena di Kantor Imigrasi Kelas I Makassar tersebut masyarakat masih mengalami pelayanan yang lambat dan masyarakat masih sering di persulit dalam pengurusan paspor tersebut.
Menurut Waluyo

(2007) Kualitas pelayanan (service quality) telah hampir menjadi faktor yang menentukan dalam menjaga keberlangsungan suatu organisasi birokrasi pemerintah maupun organisasi perusahaan. Pelayanan yang baik dan sesuai dengan kebutuhan pengguna jasa publik, sangat penting dalam upaya mewujudkan kepuasan pengguna jasa publik (customer satisfaction).

Menurut Lewis \& Booms dalam Tjiptono mendefinisikan kualitas pelayanan secara sederhana, yaitu ukuran seberapa bagus tingkat layanan yang diberikan mampu sesuai dengan ekspektasi pelanggan. Artinya kualitas pelayanan ditentukan oleh kemampuan perusahaan atau lembaga tertentu untuk memenuhi kebutuhan yang sesuai dengan apa yang diharapkan atau diinginkan berdasarkan kebutuhan pelanggan/pengunjung.

Apabila jasa yang diterima atau dirasakan (perceived service) sesuai dengan yang diharapkan, maka kualitas jasa dipersepsikan sebagai kualitas ideal. Sebaliknya jika jasa 
yang diterima lebih rendah dari pada yang diharapkan, maka kualitas jasa yang dipersepsikan buruk. Baik tidaknya kualitas jasa tergantung pada kemampuan penyedia jasa dalam memenuhi harapan pelanggannya secara konsisten.

Fokus utama dari pelayanan publik di Indonesia adalah pemenuhan kebutuhan warganegara. Hal ini menunjukkan upaya serius penyelenggaraan pelayanan yang ditujukan kepada masyarakat sebagaimana yang diutarakan oleh Osborne dan Geabler yaitu sebagai pemenuhan kebutuhan pengguna layanan bukan birokrasi penyelenggara pelayanan (meeting the needs of costumer not the bureaucracy). David Osborne dan Ted Geabler (2005)

Menurut Triguno mengartikan kualitas sebagai standar yang harus seseorang, kelompok, lembaga, atau organisasi mengenai kualitas sumber daya kerja, kualitas cara kerja, proses dan hasil kerja atau produk yang berupa barang dan jasa.

Menurut Stanton, pelayanan adalah kegiatan yang dapat diidentifikasikan dan tidak berwujud dan merupakan tujuan penting dari suatu rencana transaksi, guna memberikan kepuasan kepada konsumen (Hasibuan, 2005)

Menurut Litjan Poltak Sinambela, dkk (2006) pelayanan publik diartikan "pemberian layanan (melayani) keperluan orang atau masyarakat yang mempunyai kepentingan pada organisasi tertentu sesuai dengan aturan pokok dan tata cara yang telah ditetapkan."

Menurut H.A.S Moenir (2006) menyatakan: "Pelayanan umum adalah suatu usaha yang dilakukan kelompok atau seseorang atau birokrasi untuk memberikan bantuan kepada masyarakat dalam rangka mencapai suatu tujuan tertentu."

Aparat negara atau aparatur pemerintah, diharapkan atau dituntut adanya kemampuan baik berupa pengetahuan, keterampilan serta sikap perilaku yang memadai, sesuai dengan tuntutan pelayanan dan pembangunan sekarang ini. sementara itu, konsep lain mendefinisikan kemampuan atau ability sebagai sifat yang dibawa 
lahir atau dipelajari yang baik pendidikannya maupun memungkinkan seseorang melakukan sesuatu yang bersifat mental atau fisik (Bibson, 2003).

Setiap pelayanan publik perilakunya.

Unsur pendukung lainnya adalah sarana dan prasarana. Dengan tersedianya sarana dan memang diperlukan adanya prasarana yang lengkap, petugas kejelasan informasi prosedur yang juga akan mudah memberikan mudah dan tidak berbelit serta layanan. Unsur yang terakhir adalah dibutuhkan usaha dari pemberi masyarakat sebagai pengguna pelayanan agar dapat berjalan tertib dan lancar. Seperti contohnya layanan. Masyarakat mempunyai hak untuk mendapatkan pelayanan petugas menerapkan sistem antri agar pelayanan dapat berjalan tertib. yang baik dari petugas pelayanan.

Tetapi selain memiliki hak, Unsur yang juga penting selain masyarakat juga mempunyai sistem, prosedur dan metode adalah unsur personil juga memiliki peranan penting dalam mewujudkan pelayanan yang baik.

Petugas yang memiliki kemampuan yang sesuai dengan bidangnya pasti akan melaksanakan tugasnya dengan baik dan memberikan layanan yang baik juga. Oleh karena itu, dibutuhkan petugas pelayanan yang profesional untuk memberikan kepuasan kepada pengguna layanan. Selain profesional, petugas harus melayani dengan ramah dan sabar, mengingat masyarakat sangatlah heterogen kewajiban untuk mematuhi prosedur pelayanan yang telah ditetapkan petugas agar terjadi keseimbangan hak dan kewajiban baik penerima layanan maupun pemberi layanan. Untuk menentukan kualitas pelayanan paspor di kantor imigrasi kelas I makassar, digunakan teori yang di kemukakan oleh Parasuraman, Berry dan Zethaml (Ratminto \& Septi Winarsih, 2005) yang terdiri atas 5 dimensi kualitas pelayanan yaitu : 1) Bukti Langsung (Tangible), yaitu : sebagai fasilitas yang dapat dilihat dan di gunakan perusahaan dalam upaya memenuhi kepuasan pelanggan,seperti gedung 
kantor, peralatan kantor, penampilan karyawan dan lain lain. 2) Kehandalan (Reliability), yaitu : kemampuan memberikan pelayanan kepada pelanggan sesuai dengan yang di harapkan, seperti kemampuan dalam menempati janji, kemampuan memecahkan masalah dan kemampuan untuk meminimkan kesalahan. 3) Daya Tanggap (Responsiveness), yaitu sebagai sikap tanggap, mau mendengarkan dan merespon pelanggan dalam upaya memuaskan pelanggan, misalnya : mampu memberikan informasi secara benar dan tepat, tidak menunjukan sikap sok sibuk dan mampu memberikan pertolongan dengan segera. 4) Jaminan (Assurance), yaitu :kemampuan karyawan dalam menimbulkan kepercayaan dan keyakinan pelanggan melalui pengetahuan,kesopanan serta menghargai perasaan pelanggan. 5) Perhatian (Emphaty), yaitu : kemampuan atau kesediaan karyawan memberikan perhatian yang bersifat pribadi, seperti bersikap ramah, memahami kebutuhan dan peduli kepada pelanggannya.

Paspor adalah dokumen perjalanan yang dikeluarkan oleh pemerintah kepada warga negaranya dimana pemerintah memberi hak kepada yang bersangkutan untuk dapat melakukan perjalanan ke luar negeri dan di dalamnya tertera identitas yang sah, kewarganegaraan, dan hak perlindungan selama berada di luar negeri, dan hak untuk kembali ke tanah air.

\section{METODE PENELITIAN}

Waktu penelitian ini dilaksanakan dari bulan Maret hingga Juni 2017. Adapun menjadi penentuan lokasi penelitian adalah Kantor Imigrasi Kelas I Makassar.

Jenis penelitian ini adalah penelitian kualitatif dan tipe penelitian adalah pendekatan fenomenologi deskriptif yaitu menekankan pada subyektivitas pengalaman hidup manusia.

Jumlah informan sebanyak 13 orang. Teknik pengumpulan data dikumumpulkan dengan menggunakan instrumen berupa 
observasi dan wawancara dengan metode tanya jawab atau percakapan dengan para informan untuk memperoleh data baik dengan menggunakan daftar pertanyaan atau percakapan bebas yang berhubungan dengan permasalahan yang telah dirumuskan sebelumnya.

Sumber data yang digunakan dalam penelitian ialah data primer yaitu data yang diperoleh langsung dari lokasi penelitian berupa wawancara dan data sekunder yang diperoleh dari dokumen-dokumen dan catatan yang dapat mendukung kelengkapan data primer.

\section{HASIL DAN PEMBAHASAN}

Berdasarkan dengan tujuan penelitian ini yang tercantum pada bab sebelumnya yaitu, untuk mengetahui bagaimana Kualitas Pelayanan Dalam Pengurusan Paspor Di Kantor Imigrasi Kelas I Makassar dan Apa Faktor Pendukung dan Penghambat Dalam Pengurusan Paspor di Kantor Imigrasi Kelas I Makassar.

Layanan masyarakat di Kantor Imigrasi Kelas I Makassar dilaksanakan berdasarkan Undang-
Undang No. 6 Tahun 2011 Tentang Keimigrasian. Peningkatan kualitas pelayanan kepada masyarakat melalui pelayanan prima yang berorientasi pada kepentingan masyarakat, berintegritas, responsive, akuntabel serta profesional semua itu adalah tujuan dari Kantor Imigrasi Kelas I Makassar dalam melaksanakan tugas. Semua tugas dan kewajiban yang menyangkut pelayanan terhadap masyarakat menjadi kewajiban setiap pegawai di Kantor Imigrasi Kelas I Makassar.

Pada dasarnya, terdapat beragam alat ukur, tolok ukur, parameter, atau indikator kualitas layanan publik karena pihak yang menentukan kualitas beragam, berikut sudut pandangnya. Secara sederhana dapat dikatakan kualitas pelayanan dapat diketahui dengan cara membandingkan persepsi pelanggan atas pelayanan yang kenyataannya mereka terima atau peroleh dengan pelayanan yang sesungguhnya mereka harapkan atau inginkan. Jika kenyataan lebih dari yan diharapkan, maka pelayanan dapat dikatakan bermutu. 
Sedangkan jika kenyataannya kurang dari yang diharapkan, maka pelayanan dapat dikatakan tidak bermutu. Apabila kenyataan sama dengan harapan maka pelayanan tersebut memuaskan.

Pelayananan publik akan memimiliki kualitas pelayanan yang tinggi apabila acuan utama penyelenggaranannya selalu berorientasi kepada pengguna jasa. Kepuasan pelanggan harus selalu mendapat perhatian dalam setiap penyelenggaranan pelayanan publik, karena merekalah penguasa yang memberikan pelayanan, merekalah berhak atas pelayanan yang terbaik diberikannya. Untuk acuan penyelenggaranan pelayanan publik harus senantiasa berorientasi pada kebutuhan masyarakat.

Untuk menentukan kualitas pelayanan paspor di Kantor Imigrasi Kelas I Makassar, beberapa teori indikator kualitas pelayanan yang di kemukakan oleh Parasuraman, Berry dan Zethaml ( Ratminto \& Septi Winarsih, 2005 ) yang mengemukakan bahwa ada 5 indikator untuk mengukur kualitas layanan adalah : 1) Bukti Langsung
(Tangible), yaitu : sebagai fasilitas yang dapat dilihat dan di gunakan perusahaan dalam upaya memenuhi kepuasan pelanggan,seperti gedung kantor, peralatan kantor, penampilan karyawan dan lain lain. 2) Kehandalan (Reliability), yaitu : kemampuan memberikan pelayanan kepada pelanggan sesuai dengan yang di harapkan, seperti kemampuan dalam menempati janji, kemampuan memecahkan masalah dan kemampuan untuk meminimkan kesalahan. 3) Daya Tanggap (Responsiveness), yaitu sebagai sikap tanggap, mau mendengarkan dan merespon pelanggan dalam upaya memuaskan pelanggan, misalnya : mampu memberikan informasi secara benar dan tepat, tidak menunjukan sikap sok sibuk dan mampu memberikan pertolongan dengan segera. 4) Jaminan (Assurance), yaitu :kemampuan karyawan dalam menimbulkan kepercayaan dan keyakinan pelanggan melalui pengetahuan,kesopanan serta menghargai perasaan pelanggan. 5) Perhatian (Emphaty), yaitu : kemampuan atau kesediaan 
karyawan memberikan perhatian yang bersifat pribadi, seperti bersikap ramah, memahami kebutuhan dan peduli kepada pelanggannya.

Kualitas pelayanan yang dilihat dari indikator tangibel (bukti fisik) pada umumnya di katakan baik melihat prosedur pelayanan sudah sederhana dan dapat dipahami oleh masyarakat. Akan tetapi, dalam hal ini masih banyak pemohon yang mengeluhkan tentang fasilitas prasarana seperti lahan parkir yang kurang luas sedangkan setiap tahunnya masyarakat yang datang untuk mengurus paspor semakin meningkat serta sistem jaringan yang masih sering mengalami kerusakan sehingga proses pelayanan menjadi terhambat. Maka dalam dimensi ini masih belum dapat dikatakan berkualitas dan belum tercapai secara maksimal.

Kami selalu berusaha untuk melengkapi setiap fasilitas sarana dan prasarana yang ada untuk membantu masyarakat agar mudah dalam melakukan proses pelayanan dan hal ini juga sangat membantu petugas dalam melayani masyarakat agar semuanya lancar. kami juga sangat mengharapkan dengan adanya fasilitas ini masyarakat yang mengurus paspor bisa merasa nyaman dan puas selama mengikuti proses pelayanan. Hal tersebut sesuai dengan hasil observasi peneliti selama dilapangan yang menemukan bahwa segala proses pelayanan berjalan lancar dimana hal ini terlihat dari ketersediaan fasilitas yang ada dalam Kantor Imigrasi Kelas I Makassar.

Kendalanya itu lahan parkir karena kurang luas sedangkan pengunjungnya banyak, orang juga susah dapat tempat parkir. Untuk bagian prasarana di Kantor Imigrasi Kelas I Makassar masih kurang memadai untuk di gunakan dalam pemberian layanan karena volume pengunjung yang semakin meningkat sedangkan fasilitas yang di sediakan sekarang ini masih kurang luas. Hal tersebut sesuai dengan hasil observasi peneliti selama di lapangan yang menemukan bahwa ada beberapa keluhan yang seringkali dirasakan oleh masyarakat dalam hal pelayanan diantaranya yaitu 
masalah lahan parkir yang kurang memadai sehingga masyarakat yang datang mengurus paspor terkadang merasa kesulitan dalam memarkir kendaraan sedangkan volume pengunjung setiap tahunnya semakin meningkat.

Kehandalan (Reliability), yaitu : merupakan kemampuan memberikan pelayanan yang memuaskan, seperti ketepatan waktu dalam melayani, kecepatan dan kecermatan dalam penyelesaiaan pelayanan. Keandalan disini merupakan sejauh mana para aparatur dapat secara cepat, tepat dan cermat dalam setiap pemberian pelayanan kepada masyarakat.

Pelayanan yang diberikan sudah sesuai dengan standar pelayanan. jadi masyarakat cukup mengikuti prosedurnya yaitu pemohon mengambil nomor antrian, kemudian melengkapi persyaratan yang ada. Saya sebagai petugas loket memeriksa berkas-berkas yang di serahkan oleh pemohon kemudian selanjutnya ke bagian wawancara dan foto dan apabila ada persyaratan yang tidak lengkap maka loket akan menyampaikan untuk di lengkapi kembali persyaratannya dan apabila dalam persyaratan itu ada yang tidak sesuai maka kita akan menyampaikannya. proses yang dijalankan oleh petugas terhadap pelayanan yang diberikan kepada masyarakat telah sesuai dengan prosedur pelayanan yang ada. Hal ini cukup sederhana dan memudahkan masyarakat untuk mengurus paspor di Kantor Imigrasi Kelas I Makassar.

Hal tersebut sesuai dengan hasil observasi peneliti selama di lapangan yang menemukan bahwa petugas dalam menjalankan tugasnya sudah sesuai dengan prosedur yang ada, dimana apabila ada ada persyaratan yang tidak lengkap maka petugas loket akan menyampaikan untuk di lengkapi kembali persyaratannya dan apabila dalam persyaratan itu ada yang tidak sesuai maka petugas loket akan menyampaikannya. Sehingga seluruh proses pelayanan berjalan sesuai dengan aturan yang berlaku.

Cukup mudah, karena pada saat pengurusan paspor kita tinggal 
melengkapi KK, KTP, dan AKTA Kelahiran setelah itu kita tinggal menunggu nomor antrian dipanggil untuk dilayani. Dalam prosedur pembuatan paspor sebenarnya mudah selama pemohon yang ingin mengurus paspor memenuhi persyaratan yang ada. Hal tersebut sesuai dengan observasi peneliti selama di lapangan yang menemukan bahwa tingkat kemudahan dalam pengurusan paspor di Kantor Imigrasi Kelas I Makassar dapat dikatakan cukup mudah.

Sudah terperinci, segala biaya yang dibebankan kepada masyarakat terperinci dengan secara jelas. Transaksi pembayaran di lakukan langsung di Bank. pihak Kantor Imigrasi Kelas I Makassar secara transparan dan terperinci menjelaskan biaya yang dibebankan kepada pemohon yang ingin mengurus paspor. Seluruh biaya pengurusan paspor secara langsung dibayar di Bank.

Kualitas pelayanan yang dilihat dari indikator responsiveness (daya tanggap) dapat dikatakan baik dimana petugas yang memberikan pelayanan cukup tanggap dan mampu memberikan petolongan dengan segera.

Tadi pada saat pengumpulan berkas petugasnya juga cepat tanggap, saya bertanya dia juga merespon dengan baik. Petugas dalam melayani pemohon cukup tanggap dan bersikap sopan terhadap pemohon yang datang mengurus paspor di Kantor Imigrasi Kelas I Makassar, hal ini sesuai dengan prinsip pelayanan imigrasi yaitu 5S : senyum, salam, sapa, sopan dan santun. Dapat disimpulkan bahwa kualitas pelayanan dalam variabel ini sudah tercapai dan dapat dikatakan berkualitas

Jaminan (Assurance) adalah kemampuan karyawan dalam menimbulkan kepercayaan dan keyakinan pelanggan melalui pengetahuan, kesopanan serta menghargai perasaan pelanggan, keterampilan dalam memberikan informasi, kemampuan dalam memberikan keamanan di dalam memanfaatkan jasa yang ditawarkan. Sikap kesopanan, kejujuran, dan dapat menunjukkan 
sosok pribadi yang menyenangkan melalui cara berpenampilan. Kualitas pelayanan yang dilihat dari indikator Assurance ( Jaminan ) sudah tercapai secara maksimal Banyaknya masyarakat yang datang sudah seharusnya mendapatkan kenyamanan selama pelayanan yaitu dengan cara memberikan rasa aman bagi masyarakat selama pelayanan, baik dilingkungan kantor maupun di luar kantor. Oleh sebab itu, perlu adanya suatu perbaikan pelayanan untuk memberikan rasa aman bagi masyarakat selama pelayanan.

Untuk keamanan saya rasa sudah cukup aman karena di luar sudah disediakan area parkir dan ada juga tukang parkir yang menjaga kendaraan. Segi keamanan yang disediakan oleh pihak Kantor Imigrasi Kelas I Makassar sudah cukup baik sehingga masyarakat merasa aman. Upaya meningkatkan kualitas pelayanannya terkait memberikan rasa aman bagi masyarakat yaitu dengan menempatkan tukang parkir yang ikut mengamankan keadaan di parkiran.
Petugasnya cukup ramah dan sopan karena biasanya kita lihat ada petugas yang tidak sopan atau kalau kita bertanya petugasnya sok sibuk. kualitas pelayanan petugas dalam memberikan pelayanan kepada setiap pelanggan atau pemohon yang membutuhkan pelayanan sudah memberikan pelayanan yang baik kepada pemohon.

Empathy (perhatian) yaitu syarat untuk peduli, memberi perhatian pribadi bagi pelanggan. Empati meliputi perhatian secara individual yang diberikan kantor kepada masyarakat, seperti kemudahan untuk menghubungi kantor, kemampuan pegawai untuk berkomunikasi dengan masyarakat. Kualitas pelayanan yang dilihat dari indikator Empathy (Perhatian) dapat dikatakan baik, karena pelayanan yang diberikan oleh petugas kepada masyarakat sepenuhnya dapat dikatakan baik dan petugas melayani dengan sikap ramah juga sopan santun,. Namun, masih ada beberapa kekuragan dimana masih ada oknum pegawai yang bertindak secara diskriminatif (membedabedakan) dimana pelayanan masih 
belum bisa menghilangan sifat mudah dan lancar, terutama bagi patron/ kekeluargaan, orang dekat kami seorang petugas tentu sangat dan orang yang dikenal. Dan itu membutuhkan fasilitas penunjang yang menjadikan pendahuluan seperti komputer, print dan mesin pelayanan terhadap orang-orang tersebut.

Tadi saya terlambat kemudian datang jam 10 tapi pendafataran nomor antriannya sudah tutup, tapi untung karena ada keluarga di dalam yang mengurus akhirnya saya dapat nomor antrian. masih ada oknum-oknum petugas yang bertindak tidak adil terhadap masyarakat yang mengurus paspor, hanya karena keluarga yang datang mengurus sehingga pelayanannya masih lebih di dahulukan dari pada pemohon yang lebih dulu mengantri.

Beberapa faktor yang menjadi pendukung dan penghambat dalam proses pelayanan yaitu faktor pendukungnya adalah Sarana Pelayanan dimana fasilitas sarana yang disediakan oleh pihak Imigrasi Kelas I Makassar berfungsi untuk memudahkan para petugas dalam memenuhi kebutuhan masyarakat.

Dengan adanya fasilitas sarana prasarana semua pekerjaan menjadi foto copy. fasilitas sarana prasarana merupakan faktor pendukung dalam menunjang kualitas pelayanan. Segala aktivitas petugas menjadi lancar dan tepat waktu. Hal ini juga sangat memudahkan petugas dalam menyelesaikan pekerjaannya setiap hari kerja.

Sedangkan

faktor penghambatnya adalah kesadaran masyarakat yang kurang. Kesadaran masyarakat dimaksudkan ialah kesadaran untuk mempersiapkan segala yang menjadi persyaratan untuk melakukan suatu urusan pelayanan di Kantor Imigrasi Kelas I Makassar, relasi antara petugas layanan dengan masyarakat memang harus saling mendukung agar dapat mencapai tujuan yang di harapkan, baik itu dari pihak masyarakat maupun dari pihak petugas itu sendiri.

Biasanya memang ada masyarakat yang datang sudah mengantri dari pagi tapi berkasberkas yang di bawa itu tidak 
memenuhi persyaratan jadi biasanya kami sampaikan untuk di lengkapi kembali dan tugas kami hanya menjalankan pelayanan sesuai dengan prosedur. Yang menjadi penghambat dalam pengurusan paspor adalah kurangnya kesadaran masyarakat dalam melengkapi berkas sehingga pelayanan tidak dapat di lakukan. Hal ini tentu menjadi pemicu utama karena masyarakat kurang menyadari bahwa dalam pengurusan paspor perlu kesiapan untuk melengkapi berkas-berkas yang diperlukan. Hal tersebut sesuai dengan hasil observasi peneliti selama di lapangan yang melihat bahwa biasanya memang ada pemohon yang datang mengurus paspor tetapi berkas-berkas yang di bawa tidak sesuai dengan persyaratan. Pada akhirnya pemohon yang lebih dulu mengantri harus kembali untuk melengkapi berkas yang kurang lengkap.

\section{KESIMPULAN}

Kualitas Pelayanan Dalam Pengurusan Paspor di Kantor Imigrasi Kelas I Makassar belum tercapai secara maksimal hal ini terlihat dari aspek : Empathy (Perhatian ) yaitu karena masih ada kekurangan dalam sistem pelayanan sehingga menyebabkan ada penyelonongan pelanggan dalam meminta pelayanan. Hal itu terjadi disebabkan oleh beberapa hal antara lain; pelanggan yang mengenal petugas jaga yang ada di depan loket, sehingga pelanggan langsung menuju orang yang dikenal tersebut untuk meminta pelayanan tanpa menghiraukan pelanggan yang sudah antri sebelum dia. Dalam hal ini juga dapat menjadikan celah untuk adanya diskriminasi dalam pelayanan.

Kualitas pelayanan pada aspek lainnya sudah tercapai secara maksimal yaitu (1) dimensi tangible ( bukti langsung ) dimana fasilitas sarana yang sudah memadai sehingga memudahkan masyarakat maupun petugas dalam pengurusan paspor di Kantor Imigrasi Kelas I Makassar, (2) dimensi reliability (Kehandalan) dimana petugas memberikan pelayanan yang dijanjikan dengan segera, akurat dan memuaskan, seperti ketepatan 
waktu, kecepatan dan kecermatan dalam penyelesaiaan pelayanan hal ini sudah tercapai secara maksimal. (3) kualitas layanan di lihat dari aspek dimensi Responsiveness (Daya Tanggap) sudah tercapai secara maksimal karena petugas dalam pelayanan memiliki sikap cepat tanggap, mau mendengarkan dan merespon pelanggan dalam upaya memuaskan pelanggan seperti kemampuan petugas dalam membantu masyarakat yang bermasalah dengan pelayanan dan keluhan, serta ketersediaan wadah untuk menampung aspirasi, saran dan keluhan dari masyarakat, mampu memberikan informasi secara benar dan tepat, tidak menunjukkan sikap sok sibuk dan mampu memberikan pertolongan dengan segera. Kemudian kualitas pelayanan pada aspek Assurance (Jaminan) sudah maksimal dimana terjaminnya suatu keamana dalam proses pelayanan kemudian petugas dalam pengetahuan, keahlian, keterampilan, sikap dan perilaku petugas sudah baik dan tercapai secara maksimal.
Faktor Pendukung dalam pelayanan adalah fasilitas sarana dan prasarana sudah terlaksana secara optimal. bahwa dengan adanya fasilitas pendukung dalam kantor Imigrasi Kelas I Makassar seluruh kegiatan maupun pekerjaan yang dibebankan kepada petugas menjadi lebih mudah dan lancar.

Faktor Penghambat dalam pelayanan adalah kurangnya kesadaran masyarakat dimana kesadaran masyarakat dimaksudkan ialah kesadaran untuk mempersiapkan segala yang menjadi persyaratan untuk melakukan suatu urusan pelayanan di Kantor Imigrasi Kelas I Makassar, relasi antara petugas layanan dengan masyarakat memang harus saling mendukung agar dapat mencapai tujuan yang di harapkan, baik itu dari pihak masyarakat maupun dari pihak petugas itu sendiri.

\section{DAFTAR PUSTAKA}

Bibson, 2003. Pelayanan Sektor Publik. ANDI : Yogyakarta

Hasibuan, Malayu S.P. 2005. Manajemen Sumber Daya 
Manusia, Edisi Revisi. Bumi Aksara, Jakarta.

Moenir, H.A.S. 2006. Manajemen Pelayanan Umum di Indonesia. Jakarta: Bumi Aksara.

Osborne, David dan Ted Geabler. 2005. Mewirausahakan Birokrasi: Menstransformasi Semangat Wirausaha ke Dalam Sektor Publik. diterjemahkan oleh Abdul.Rosyid, Jakarta: PPM.

Poltak Sinambela, Litjan dkk. 2006. Reformasi Pelayanan Publik: Teori, Kebijakan, dan Implementasi. Jakarta: Bumi Aksara.

Ratminto dan Atik Septi Winarsih. 2005. Manajemen Pelayanan. Yogyakarta: Pustaka Belajar.

Sagita, 2010. Peran Kualitas Pelayanan Pelanggan
Tentang Prosedur

Pemasangan Jaringan Baru dan Perubahan Daya Listrik PT PLN (Pesero) Area Pelayanan Jaringan Surabaya Selatan. Surabaya: Perpustakaan STIKOM Surabaya

Tjiptono, Fandy. 2012. Strategi Pemasaran. Edisi Kedua. Yogyakarta : Andi.

Triguno. 2000. Budaya Kerja Menciptakan Iklim Yang Kondusif Untuk Meningkatkan Produktivitas Kerja. Golden Terayon Press, Jakarta

Waluyo, 2007. Manajemen Publik. Konsep, Aplikasi \& Implementasinya Dalam Pelaksanaan Otonomi Daerah. Bandung: Mandar Maju. 